\title{
Recent trends in the prevalence of byssinotic symptoms in the Lancashire textile industry
}

\author{
F F CINKOTAI, ${ }^{1}$ A RIGBY, ${ }^{2}$ C A C PICKERING, ${ }^{3}$ D SEABORN, ${ }^{1}$ E FARAGHER ${ }^{2}$ \\ From the Department of Occupational Health, ${ }^{1}$ University of Manchester, Withington Hospital, ${ }^{2}$ and \\ Wythenshawe Hospital, ${ }^{3}$ Manchester, UK
}

\begin{abstract}
A respiratory symptoms questionnaire was completed for 4656 volunteers employed in 31 textile factories engaged in spinning or weaving manmade fibre or cotton of various qualities. Sets of airborne dust and bacteria samples were collected in workzones and personal breathing zones in the workrooms where the volunteers were employed. A total of 182 people indicated experiencing byssinotic symptoms, mainly in opening and carding rooms or in spinning and winding rooms where medium to coarse cotton was being processed. This represents a significant decline in the prevalence of byssinotic symptoms over the years, due possibly to lower concentrations of airborne contaminants, especially of bacteria, as cleaner raw materials are being used. According to a multiple, logistic regression model, the prevalence of byssinotic symptoms was found to be statistically significantly related to years worked in the cotton industry, exposure to dust, quality of cotton used, workroom of employment, ethnic origin, and smoking habits. Symptoms of chronic bronchitis were found to be significantly related to smoking habit and to factors connected with occupation, such as exposure to dust, workroom, and the quality of fibre processed.
\end{abstract}

Although the presence of byssinotic symptoms in cotton spinners and fibre preparers had been known for at least a hundred years, the first systematic epidemiological study was undertaken only in the 1950 s by Schilling and his colleagues. ${ }^{1}$ The raw cotton was carded and spun in the 1950s by machines that were not equipped with dust suppression devices. In the cardrooms of three Lancashire spinning mills using "coarse" cotton Schilling and Roach measured airborne dust concentrations ranging from $1 \cdot 1 \mathrm{mg} / \mathrm{m}^{3}$ to $13.7 \mathrm{mg} / \mathrm{m}^{3}$ and found that more than $51 \%$ of people working in the rooms suffered from byssinotic symptoms of varying severity. ${ }^{2}$

During subsequent years some form of local exhaust ventilation was installed into the machines and this has led to a visible reduction in airborne dust. Nevertheless, in the cardrooms of five coarse mills in Lancashire, Molyneux and Tombleson still observed mean dust concentrations of $0.94 \mathrm{mg} / \mathrm{m}^{3}$ to $5.33 \mathrm{mg} /$ $\mathrm{m}^{3}$ and found that 202 of $514(39 \%)$ people employed in the cardrooms studied suffered from some grade of byssinosis. ${ }^{3}$ In the mid-1970s Cinkotai and Whitaker found that dust concentrations on average exceeded $1 \mathrm{mg} / \mathrm{m}^{3}$ but not $4 \mathrm{mg} / \mathrm{m}^{3}$ in nine of the 21 cardrooms studied; 85 of $469(18 \%)$ workers in these "dusty" workrooms suffered from byssinotic symptoms. ${ }^{4}$

Accepted 27 October 1987
Although trends in the prevalence of byssinotic symptoms among cotton spinners were clearly downwards toward the mid-1970s, whether or not this was due to declining airborne contamination because of the installation of increasingly more efficient dust suppression devices was difficult to determine. Considering that the sampling instruments used for estimating the concentration of airborne dust in the different surveys varied widely, the concentrations of airborne dust in cardrooms reported over the years were remarkably similar. One purpose of the survey presently reported was to study the trends in the prevalence of byssinotic symptoms in the light of many recent changes in the fibre preparing industry, such as the installation of further dust suppression devices, the use of cleaner raw cotton, the elimination of the dustiest trades through mechanisation or automation, the retirement or redundancy of the older generation who had been exposed to particularly high concentrations of airborne dust in the distant past, and the closure of the dustiest factories.

Other aims were $(a)$ to investigate the use of a personal sampling head for estimating personal exposure to airborne cotton dust and $(b)$ to study the byssinotic symptoms in relation to other respiratory symptoms prevalent among cotton spinners. Reports on these subjects will be published elsewhere. 
Table 1 Distribution of sex, race, smoking habit, and work experience among the people interviewed

\begin{tabular}{|c|c|c|c|c|c|c|c|c|}
\hline Mill & Int & Male & Eur & Ind & Smok & Non-sm & $<10 y$ & $>20 y$ \\
\hline $\begin{array}{r}1 \\
2 \\
3 \\
4 \\
5 \\
6 \\
7 \\
8 \\
9 \\
10 \\
11 \\
12 \\
13 \\
14 \\
15 \\
16 \\
17 \\
18 \\
19 \\
20 \\
22 \\
23 \\
24 \\
25 \\
26 \\
29 \\
30 \\
31 \\
32 \\
33 \\
34\end{array}$ & $\begin{array}{r}140 \\
208 \\
228 \\
89 \\
130 \\
152 \\
30 \\
40 \\
184 \\
158 \\
153 \\
217 \\
63 \\
95 \\
286 \\
211 \\
78 \\
282 \\
268 \\
234 \\
148 \\
39 \\
57 \\
88 \\
288 \\
563 \\
50 \\
95 \\
49 \\
20 \\
13\end{array}$ & $\begin{array}{r}116 \\
139 \\
168 \\
78 \\
77 \\
89 \\
18 \\
40 \\
111 \\
100 \\
118 \\
163 \\
20 \\
58 \\
179 \\
168 \\
54 \\
103 \\
161 \\
133 \\
73 \\
36 \\
44 \\
81 \\
163 \\
429 \\
43 \\
74 \\
41 \\
9 \\
2\end{array}$ & $\begin{array}{r}73 \\
115 \\
104 \\
53 \\
81 \\
97 \\
29 \\
14 \\
148 \\
75 \\
32 \\
123 \\
58 \\
63 \\
184 \\
75 \\
50 \\
166 \\
88 \\
228 \\
117 \\
31 \\
43 \\
83 \\
232 \\
348 \\
40 \\
74 \\
48 \\
20 \\
13\end{array}$ & $\begin{array}{r}64 \\
90 \\
122 \\
36 \\
46 \\
50 \\
1 \\
26 \\
35 \\
80 \\
120 \\
91 \\
5 \\
32 \\
94 \\
136 \\
28 \\
115 \\
180 \\
6 \\
30 \\
8 \\
14 \\
3 \\
56 \\
215 \\
10 \\
21 \\
1 \\
-\quad \\
-\quad\end{array}$ & $\begin{array}{r}78 \\
102 \\
98 \\
46 \\
62 \\
62 \\
19 \\
23 \\
97 \\
55 \\
53 \\
115 \\
31 \\
43 \\
150 \\
132 \\
33 \\
123 \\
84 \\
119 \\
63 \\
12 \\
19 \\
45 \\
150 \\
297 \\
23 \\
36 \\
23 \\
11 \\
7\end{array}$ & $\begin{array}{r}44 \\
80 \\
105 \\
34 \\
53 \\
72 \\
7 \\
11 \\
60 \\
84 \\
88 \\
79 \\
22 \\
37 \\
101 \\
66 \\
38 \\
128 \\
164 \\
85 \\
59 \\
19 \\
18 \\
34 \\
95 \\
183 \\
18 \\
42 \\
13 \\
5 \\
5\end{array}$ & $\begin{array}{r}62 \\
96 \\
103 \\
46 \\
49 \\
66 \\
19 \\
19 \\
104 \\
77 \\
91 \\
82 \\
13 \\
23 \\
175 \\
65 \\
27 \\
119 \\
123 \\
137 \\
68 \\
7 \\
25 \\
51 \\
143 \\
267 \\
24 \\
38 \\
27 \\
14 \\
5\end{array}$ & $\begin{array}{r}40 \\
46 \\
45 \\
18 \\
33 \\
45 \\
5 \\
5 \\
44 \\
43 \\
14 \\
75 \\
36 \\
35 \\
51 \\
61 \\
31 \\
72 \\
52 \\
44 \\
34 \\
27 \\
16 \\
26 \\
71 \\
130 \\
15 \\
28 \\
15 \\
2 \\
4\end{array}$ \\
\hline Total & 4656 & 3088 & 2905 & 1715 & 2211 & 1849 & 2203 & 1163 \\
\hline
\end{tabular}

Mill, mill number; Int, number of people interviewed; Eur, European; Ind, from the Indian subcontinent; Smok, smoker; Non-sm, non-smoker; $y$, years of work experience.

Table 2 Number of individuals suffering, according to the respiratory symptoms questionnaire, from persistent cough (pc), chronic phlegm production (cp), and byssinosis (by) among the people interviewed (in) in the carding, spinning, winding, opening*, and beaming rooms $\dagger$ of spinning mills using manmade fibre ( $\mathrm{mf})$, mixture of manmade fibre and cotton, fine cotton $(f c)$, medium cotton $(\mathrm{mc})$, coarse cotton ( $\mathrm{cc})$, and waste cotton (wc)

\begin{tabular}{|c|c|c|c|c|c|c|c|c|c|c|c|c|c|c|c|c|c|}
\hline \multirow{2}{*}{\multicolumn{2}{|c|}{ Mill fibre }} & \multicolumn{4}{|c|}{ Cardroom } & \multicolumn{4}{|c|}{ Spinning } & \multicolumn{4}{|c|}{ Winding } & \multicolumn{4}{|c|}{ Other room } \\
\hline & & $p c$ & $c p$ & by & in & $p c$ & $c p$ & by & in & $p c$ & $c p$ & by & in & $p c$ & $c p$ & by & in \\
\hline \multirow{7}{*}{$\begin{array}{rl}14 & \mathrm{n} \\
15 & \mathrm{n} \\
19 & \mathrm{n} \\
20 & \mathrm{n} \\
2 & \mathrm{n} \\
26 & \mathrm{n} \\
34 & \mathrm{n}\end{array}$} & & 13 & 7 & 3 & 71 & & & & & 6 & 4 & 0 & 24 & & & & \\
\hline & $\mathrm{mf}$ & 11 & 9 & 5 & 62 & 27 & 15 & 1 & 147 & 13 & 10 & 1 & 77 & & & & \\
\hline & $\mathrm{mf}$ & 9 & 8 & 1 & 70 & 13 & 11 & 0 & 107 & 17 & 15 & 3 & 91 & & & & \\
\hline & $\mathrm{mf}$ & 12 & 8 & 1 & 80 & 13 & 11 & 0 & 86 & 13 & 8 & 0 & 68 & & & & \\
\hline & $\mathrm{mf}+\mathrm{fc}$ & 12 & 7 & 2 & 34 & 22 & 20 & 5 & 109 & 10 & 7 & 1 & 62 & 0 & 1 & 1 & $3^{*}$ \\
\hline & $\mathrm{mf}+\mathrm{fc}$ & 20 & 17 & 4 & 84 & 26 & 13 & 1 & 134 & 6 & 5 & 0 & 70 & & & & \\
\hline & $\begin{array}{l}m f+f c \\
m f+m c\end{array}$ & 17 & 14 & 6 & 41 & 17 & 7 & 3 & 63 & $\begin{array}{l}2 \\
9\end{array}$ & 1 & 1 & 13 & & & & \\
\hline \multirow{7}{*}{$\begin{array}{r}6 \\
18 \\
10 \\
13 \\
3 \\
3 \\
5 \\
9\end{array}$} & $m f+m c$ & 12 & $\begin{array}{l}14 \\
10\end{array}$ & $\begin{array}{l}0 \\
2\end{array}$ & $\begin{array}{l}41 \\
75\end{array}$ & 31 & 22 & 3 & $\begin{array}{r}03 \\
154\end{array}$ & 12 & $\begin{array}{l}0 \\
8\end{array}$ & 0 & $\begin{array}{l}48 \\
53\end{array}$ & & & & \\
\hline & fc & 23 & 18 & 3 & 62 & 13 & 8 & 1 & 57 & 4 & 3 & 0 & 35 & 1 & 1 & 1 & $4^{*}$ \\
\hline & fc & 3 & 3 & 3 & 9 & 4 & 4 & 0 & 26 & 2 & 0 & 1 & 27 & 1 & 0 & 0 & $1^{*}$ \\
\hline & $\mathrm{mc}$ & 19 & 11 & 7 & 58 & 25 & 16 & 1 & 85 & 11 & 6 & 1 & 70 & 1 & 1 & 1 & $5^{*}$ \\
\hline & $\mathrm{mc}$ & & & & & & & & & & & & & 2 & 2 & 2 & $10 \dagger$ \\
\hline & $\mathrm{mc}$ & 16 & 9 & 7 & 34 & 23 & 16 & 2 & 60 & 5 & 4 & 1 & 36 & & & & \\
\hline & $\mathrm{mc}$ & 14 & 8 & 6 & 60 & 15 & 7 & 2 & 77 & 10 & 6 & 1 & 47 & & & & \\
\hline \multirow{4}{*}{$\begin{array}{l}16 \\
29 \\
31 \\
33\end{array}$} & $\mathrm{mc}$ & 4 & 6 & 1 & 34 & 21 & 14 & 1 & 118 & 12 & 10 & i & 59 & & & & \\
\hline & $\mathrm{mc}$ & 12 & 8 & 3 & 47 & 28 & 24 & 1 & 195 & 14 & 12 & 2 & 82 & 5 & 7 & 1 & $31 \dagger$ \\
\hline & $\mathrm{mc}$ & 10 & 6 & 5 & 26 & 12 & 9 & 1 & 47 & & & & & 6 & 5 & 0 & $22 \dagger$ \\
\hline & $\mathrm{mc}$ & & & & & & & & & & & & & 2 & 2 & 0 & $20 \dagger$ \\
\hline \multirow{7}{*}{$\begin{array}{r}1 \\
11 \\
12 \\
4 \\
7 \\
8 \\
17\end{array}$} & cc & 9 & 4 & 6 & 42 & 5 & 3 & 3 & 54 & 4 & 1 & 1 & 34 & 2 & 1 & 1 & $10^{*}$ \\
\hline & cc & 5 & 4 & 3 & 17 & 13 & 10 & 2 & 39 & 23 & 9 & 3 & 97 & & & & \\
\hline & cc & 33 & 22 & 17 & 90 & 26 & 13 & 11 & 69 & 24 & 10 & 7 & 58 & \multirow{5}{*}{17} & & & \\
\hline & wc & 15 & 12 & 8 & 48 & & & & & 13 & 9 & 3 & 41 & & \multirow{4}{*}{21} & \multirow{4}{*}{6} & \\
\hline & $\mathrm{wc}+\mathrm{mf}$ & & & & & & & & & & & & & & & & \multirow[t]{3}{*}{$30^{*}$} \\
\hline & $w c+m f$ & 9 & 3 & 2 & 13 & 22 & 4 & 1 & 27 & & & & & & & & \\
\hline & $w c+m f$ & 10 & 8 & 0 & 41 & & & & & 8 & 5 & 3 & 37 & & & & \\
\hline
\end{tabular}


Table 3 Number of individuals suffering, according to the respiratory symptoms questionnaire, from persistent cough (pc), chronic phlegm production (cp), and byssinosis (by) among the people interviewed (in) in the weaving sheds and sewing room of weaving mills using yarn spun from fine $(f c)$, medium $(\mathrm{mc})$, and coarse cotton (cc), and manmade fibre (mf)

\begin{tabular}{|c|c|c|c|c|c|c|c|c|c|}
\hline \multirow[b]{2}{*}{ Mill } & \multirow[b]{2}{*}{ Yarn } & \multicolumn{4}{|c|}{ Weaving shed } & \multicolumn{4}{|c|}{ Sewing room } \\
\hline & & $p c$ & $c p$ & by & in & $p c$ & $c p$ & by & in \\
\hline $\begin{array}{l}22 \\
23 \\
24 \\
25 \\
30 \\
29 \\
32\end{array}$ & $\begin{array}{l}\mathrm{mf}+\mathrm{fc} \\
\mathrm{mf}+\mathrm{fc} \\
\mathrm{mf}+\mathrm{fc} \\
\mathrm{mf}+\mathrm{fc} \\
\mathrm{mf}+\mathrm{fc} \\
\mathrm{mc} \\
\mathrm{cc}\end{array}$ & $\begin{array}{r}16 \\
5 \\
11 \\
12 \\
7 \\
36 \\
3\end{array}$ & $\begin{array}{r}10 \\
4 \\
5 \\
7 \\
6 \\
30 \\
5\end{array}$ & $\begin{array}{l}0 \\
0 \\
1 \\
1 \\
0 \\
3 \\
0\end{array}$ & $\begin{array}{r}93 \\
39 \\
57 \\
88 \\
50 \\
208 \\
49\end{array}$ & 13 & 10 & 2 & 55 \\
\hline
\end{tabular}

\section{Method}

\section{FACTORIES AND POPULATION}

Thirty one textile factories were surveyed (tables 1-3) embracing mills spinning yarn from manmade fibre and raw cotton of various grades and weaving sheds using the yarn. All 80 major workrooms where at least five people were employed and airborne dust occurred in significant amounts such as cardrooms, spinning, winding and beaming rooms, or weaving sheds were included in the study. Most of these workrooms were both ventilated and humidified. Blends of cotton fibre spun usually originated in several different countries and were stored before use for no longer than four weeks. All people employed in these factories worked from Monday to Friday and their work pattern included day, morning, afternoon, and night shifts.

\section{RESPIRATORY SYMPTOMS QUESTIONNAIRE}

Each consenting person who spent most of his or her worktime in one of the workrooms studied answered a respiratory symptoms questionnaire. The questions were asked by a trained nurse from a "lap-top" microcomputer (Tandy TRS 80, model 100) programmed both to display the questions and to store the answers which were then transferred to the memory file of a mainframe computer for analysis. The questionnaire, based on the BMRC Respiratory Symptoms Questionnaire, was designed $(a)$ to determine some personal details such as work experience, smoking habit, and physical fitness and $(b)$ to establish whether or not a person claimed to suffer from persistent cough, chronic phlegm production, byssinosis, asthma, or occupational asthma and humidifier fever. Byssinosis was defined as people experiencing chest tightness or breathing difficulties, or both, on the first day and possibly subsequent days of the working week that improve over the weekend or away from work. To test trends and repeatability the questionnaire was asked a second time in 11 mills two years after the first survey and the answers of people who participated on both occasions were compared. Both the questionnaire survey and airborne dust and microbe measurements were carried out between September 1983 and January 1986 although independently of one another.

\section{MEASUREMENT OF AIRBORNE DUST AND MICROBES}

The concentration of airborne dust less "fly" was measured at five strategically selected points covering evenly the workzone in a workroom. The RotheroeMitchell L60 pumps used for this purpose were set up at the sampling points at breathing height $(1.5 \mathrm{~m})$ and were operated for at least seven hours out of an eight hour workshift. The dust was collected through a wire gauze cage $(25 \mathrm{~cm} \times 25 \mathrm{~cm} \times 25 \mathrm{~cm}$ in dimensions and $2 \mathrm{~mm}$ in mesh) to exclude fly on glassfibre filters ( $26 \mathrm{~mm}$ in diameter) held on the sampling face by an aluminium holder. Filters were conditioned and weighed on a Cahn electromicrobalance both before and after sampling. Airflow through the instrument varied from $45 \mathrm{l} / \mathrm{min}$ to $65 \mathrm{l} / \mathrm{min}$ and consequently had to be frequently checked at the sampling face by using a rotameter.

Samples of airborne micro-organisms were collected by the Andersen viable sampler at points the same as those for the aerial dust samples. Six $\mathbf{3 0}$ second to two minute samples spaced evenly over a workshift were collected at each sampling point in each workroom. The microbes were impacted into petrie dishes containing either a nutrient culture medium for growing bacteria or an endoagar medium (including 0.5 units $/ \mathrm{ml}$ penicillin) for growing selectively Gramnegative organisms. The plates were incubated for 24 hours at $36^{\circ} \mathrm{C}$ and for a second 24 hour period at room temperature. Counts of colony forming units (cfu) were corrected as recommended by the instrument manufacturer. In mills where microbes occurred in significant numbers the measurements were repeated on three different workdays separated by an interval of several months.

\section{Results}

\section{PREVALENCE OF SYMPTOMS}

Of the population of 4903 employed in the workrooms studied, $4656(95 \%)$ answered the respiratory questionnaire. Of these, 1568 were women, 1715 Indians or Pakistanis, 36 black, 2211 smokers, 596 exsmokers, 354 had worked in the industry for less than a year, and 1163 for over 20 years (table 1).

Of the 4656 people interviewed, 182 indicated that they suffered from byssinotic symptoms (tables 2 and $3)$. On the basis of severity of symptoms 70 were 
Table 4 Distribution of some respiratory symptoms among 990 people in ten factories who answered the respiratory symptoms questionnaire on two occasions, firstly, in 1984 and, secondly, in 1986. (Figures in parentheses indicate the number of individuals whose symptomatological status changed from 1984)

\begin{tabular}{llllll}
\hline & \multicolumn{2}{l}{ With } & & \multicolumn{2}{l}{ Without } \\
\cline { 2 - 3 } \cline { 5 - 6 } Symptoms & 1984 & 1986 & & 1984 & 1986 \\
\hline $\begin{array}{l}\text { Byssinosis } \\
(1 / 2+1 \text { and } 2)\end{array}$ & $23+31$ & $10+34(19)$ & 936 & $946(29)$ \\
$\begin{array}{c}\text { Persistent } \\
\text { cough }\end{array}$ & 223 & $183(65)$ & 767 & $807(105)$ \\
$\begin{array}{c}\text { Chronic phlegm } \\
\text { production }\end{array}$ & 139 & $148(73)$ & & 851 & $842(64)$ \\
\hline
\end{tabular}

classed on the Schilling scale as grade $1 / 2$ byssinotics, 22 as grade 1 , and 90 as grade 2 . In spinning mills using cotton $85(10 \%)$ of the cardrooms workers (including carding and draw, speed, and combing frame operatives) $36(2 \cdot 7 \%)$ spinning room workers and 26 $(3.0 \%)$ winders suffered from byssinotic symptoms. In mills using manmade fibre only the corresponding numbers were $10(3.5 \%)$, one $(0.3 \%)$, and four $(1.5 \%)$. Only seven out of 639 interviewed in weaving sheds $(1 \cdot 1 \%)$ were found to suffer from byssinotic symptoms.

The pattern for the distribution of persistent cough and chronic phlegm production was similar to that of byssinotic symptoms (tables 2 and 3). In cardrooms $243(30 \%)$ of cotton workers suffered from persistent cough and $170(21 \%)$ from chronic phlegm production compared with $45(16 \%)$ and $32(11 \%)$ for manmade fibre workers. In spinning rooms the corresponding figures were $304(23 \%)$ and $190(14 \%)$ for cotton workers and $53(16 \%)$ and $37(11 \%)$ for manmade fibre workers. In winding rooms the prevalence of persistent cough and chronic phlegm production among cotton $(158,19 \% ; 102,11 \%)$ and manmade fibre workers, $(59,19 \% ; 37,15 \%)$, like those of byssinotic symptoms, were similar (table 2). In weaving sheds $103(16 \%)$ of those who answered the questionnaire were found to suffer from persistent cough and $77(12 \%)$ from chronic phlegm production (table 3).

Only 26 of the people interviewed indicated symptoms suggesting occupational asthma - that is, chest tightness, wheezing, and breathlessness increasing in severity over the workweek - and 12 appeared to suffer from humidifier fever. These individuals were randomly scattered around the industry.

The prevalence of byssinosis, persistent cough, and chronic phlegm production determined in 990 people in 11 factories on a second occasion two years after the first survey resembled closely the initial set of values (table 4). The association between the two sets of

Table 5 Airborne dust concentration $\left(\mathrm{mg} / \mathrm{m}^{3}\right)$ in the workzones of opening, ${ }^{*}$ carding, spinning, winding, and beaming $\dagger$ rooms of spinning mills

\begin{tabular}{|c|c|c|c|c|c|c|c|c|c|c|c|c|}
\hline \multirow[b]{2}{*}{ Mill } & \multicolumn{3}{|c|}{ Cardroom } & \multicolumn{3}{|c|}{ Spinning } & \multicolumn{3}{|c|}{ Winding } & \multicolumn{3}{|c|}{ Other workroom } \\
\hline & $\bar{N}$ & Dust & $S D$ & $N$ & Dust & $S D$ & $N$ & Dust & $S D$ & $\boldsymbol{N}$ & Dust & $S D$ \\
\hline $\begin{array}{r}14 \\
15 \\
19 \\
20 \\
2 \\
26 \\
34 \\
6 \\
18 \\
10 \\
13 \\
3 \\
3 \\
5 \\
9 \\
16 \\
29 \\
31 \\
33 \\
1 \\
11 \\
12 \\
4 \\
7 \\
8 \\
17\end{array}$ & $\begin{array}{l}2 \\
1 \\
2 \\
3 \\
2 \\
2 \\
1 \\
2 \\
2 \\
1 \\
2 \\
2 \\
2 \\
1 \\
2 \\
1 \\
2 \\
1 \\
3 \\
1 \\
1 \\
1\end{array}$ & $\begin{array}{l}0.14 \\
0.18 \\
0.51 \\
0.42 \\
0.57 \\
0.42 \\
\\
1.25 \\
0.33 \\
0.96 \\
0.22 \\
0.52 \\
0.61 \\
0.78 \\
1.70 \\
0.44 \\
0.41 \\
0.71 \\
1.41 \\
1.08 \\
0.84 \\
\\
1.01 \\
0.47\end{array}$ & $\begin{array}{l}0.12 \\
0.06 \\
0.20 \\
0.34 \\
0.26 \\
0.17 \\
0.79 \\
0.12 \\
0.23 \\
0.07 \\
0.24 \\
0.16 \\
0.30 \\
0.24 \\
0.23 \\
0.14 \\
0.29 \\
0.78 \\
0.70 \\
0.41 \\
0.51 \\
0.44\end{array}$ & $\begin{array}{l}2 \\
2 \\
1 \\
2 \\
5 \\
2 \\
4 \\
3 \\
2 \\
2 \\
1 \\
1 \\
2 \\
2 \\
5 \\
1 \\
1 \\
1 \\
1\end{array}$ & $\begin{array}{l}0.25 \\
0.20 \\
0.17 \\
0.38 \\
0.22 \\
\\
1.01 \\
0.19 \\
0.72 \\
0.26 \\
0.23 \\
1.00 \\
1.00 \\
1.63 \\
0.54 \\
0.34 \\
0.58 \\
4.02 \\
1.28\end{array}$ & $\begin{array}{l}0.07 \\
0.11 \\
0.03 \\
0.13 \\
0.11 \\
0.51 \\
0.12 \\
0.39 \\
0.13 \\
0.10 \\
0.31 \\
0.11 \\
0.73 \\
0.32 \\
0.14 \\
0.12 \\
2.09 \\
0.36\end{array}$ & $\begin{array}{l}1 \\
1 \\
1 \\
1 \\
1 \\
1 \\
1 \\
1 \\
1 \\
1 \\
2 \\
1 \\
1 \\
1 \\
1 \\
2\end{array}$ & $\begin{array}{l}0.15 \\
0.34 \\
0.09 \\
0.24 \\
0.47 \\
0.20 \\
0.20 \\
0.42 \\
0.08 \\
0.78 \\
0.33 \\
0.47 \\
\\
0.20 \\
0.45 \\
0.39 \\
0.68\end{array}$ & $\begin{array}{l}0.06 \\
0.05 \\
0.06 \\
0.05 \\
0.12 \\
0.05 \\
0.05 \\
0.06 \\
0.03 \\
0.15 \\
0.24 \\
0.22 \\
0.06 \\
0.07 \\
0.14 \\
0.58\end{array}$ & $\begin{array}{l}1 \\
1 \\
1\end{array}$ & $\begin{array}{l}0.88 \\
1.35 \\
0.51\end{array}$ & $\begin{array}{l}0.38 \dagger \\
0.37 \dagger \\
0.20 \dagger\end{array}$ \\
\hline
\end{tabular}

$\mathrm{N}$, number of workzones or workrooms where airborne dust samples were collected.

Dust, mean dust concentration based on $5^{*} \mathrm{~N}$ time weighted average values measured in the $\mathrm{N}$ number of workrooms.

$\ddagger$, Mean value based on three rather than five areal samples. 
Table 6 Airborne dust concentration $\left(\mathrm{mg} / \mathrm{m}^{3}\right)$ in the workzones of weaving sheds and sewing rooms of weaving mills

\begin{tabular}{|c|c|c|c|c|c|c|}
\hline \multirow[b]{2}{*}{ Mill } & \multicolumn{3}{|c|}{ Weaving shed } & \multicolumn{3}{|c|}{ Sewing room } \\
\hline & $N$ & Dust & $S D$ & $N$ & Dust & $S D$ \\
\hline $\begin{array}{l}22 \\
23 \\
24 \\
25 \\
30 \\
29 \\
32\end{array}$ & $\begin{array}{l}1 \\
1 \\
1 \\
1 \\
2 \\
4 \\
1\end{array}$ & $\begin{array}{l}2 \cdot 50 \\
0 \cdot 28 \\
0 \cdot 88 \\
0 \cdot 23 \\
2 \cdot 31 \\
0 \cdot 48 \\
3 \cdot 26\end{array}$ & $\begin{array}{l}0.69 \\
0.19 \\
0.16 \\
0.06 \\
0.45 \\
0.41 \\
0.65\end{array}$ & 1 & $0 \cdot 17$ & 0.07 \\
\hline
\end{tabular}

$\mathrm{N}$ as in table 5 .

answers were, according to the chi-squared test, statistically highly significant $(p<0.00005)$.

\section{AIRBORNE DUST AND BACTERIA}

In cardrooms the workzone ("static") concentration of airborne dust ranged from $0.22 \mathrm{mg} / \mathrm{m}^{3}$ to $1.70 \mathrm{mg} /$ $\mathrm{m}^{3}$ for cotton mills and from $0.18 \mathrm{mg} / \mathrm{m}^{3}$ to $0.51 \mathrm{mg} / \mathrm{m}^{3}$ for manmade fibre mills (table 5). In spinning rooms the corresponding concentrations were $0 \cdot 19-4.02 \mathrm{mg}$ / $\mathrm{m}^{3}$ and $0.17-0.25 \mathrm{mg} / \mathrm{m}^{3}$ and in winding rooms 0.08 $2.55 \mathrm{mg} / \mathrm{m}^{3}$ and $0.09-0.34 \mathrm{mg} / \mathrm{m}^{3}$. Dust concentrations in weaving sheds varied from $0.17 \mathrm{mg} / \mathrm{m}^{3}$ to $3.26 \mathrm{mg} / \mathrm{m}^{3}$ (table 6).

Airborne bacteria occurred in significant quantities in only 11 workrooms and in only three of these were the concentrations consistently above $300 \mathrm{cfu} / \mathrm{m}^{3}$ Gram-negative bacteria. These were the cardrooms of mills 11,12 , and 31 , where on average the concentrations of the Gram-negative bacteria were 1150,449, and $707 \mathrm{cfu} / \mathrm{m}^{3}$.

\section{STATISTICAL ANALYSIS}

The relation of byssinotic symptoms, persistent cough, and chronic phlegm production to $(a)$ personal particulars such as sex, years of work experience in the textile industry, or smoking habit, $(b)$ features of the manufacturing process such as workroom or quality of raw fibre processed, and $(c)$ the concentration of environmental contaminants such as airborne dust and bacteria was investigated by a stepwise, multiple logistic regression analysis.

Briefly the analysis included $(a)$ the examination of each variable (whether categorical such as sex or continuous such as dust concentration) as a potential contributor to variation in the prevalence of respiratory symptoms, $(b)$ the selection of variables in order of significance, and $(c)$ the construction of a "predictor" model from these variables. The order of significance was determined on the basis of the log-likelihood ratio (chi-squared) test. The variable
Table 7 Factors associated with byssinotic symptoms

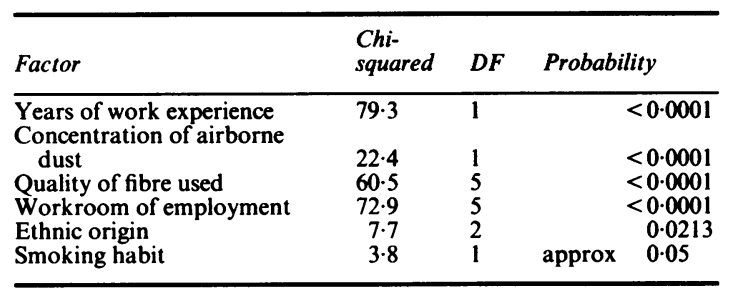

that contributed most to variation was selected first, followed by the variable which when added to the first accounted for the next most significant amount of variation and so on. The computations were performed at the University of Manchester Regional Computer Centre using the GLIM 3.77 statistical program package. 5

Factors found to be associated with the prevalence of byssinotic symptoms (table 6) were a person's work experience in the textile industry $(p<0.0001)$, the concentration of airborne dust in the workroom of employment $(p<0.0001)$, the quality of fibre processed) $p<0.0001)$, the nature of workroom $(p<0.0001)$, a person's ethnic origin $(p=0.0212)$, and smoking experience in pack-years $(\mathrm{p}=$ approx 0.05).

The probability of contracting byssinosis or some other respiratory symptom may be calculated from a predictor model as follows:

$$
\begin{aligned}
& \mathrm{p}_{\text {where }}=\operatorname{Exp}(\text { score }) /(1+\operatorname{Exp} \text { (score) }) \\
& \text { Score }=\text { Constant }+ \\
& \text { fy } x \text { work experience in years }+ \\
& \mathrm{fd} \times \text { natural } \log \text { of exposure to dust (in } \\
& \left.\mathrm{mg} / \mathrm{m}^{3}\right)+ \\
& \text { fq (for fibre quality handled) }+ \\
& \text { fqd } \times \text { natural log of exposure to dust (in } \\
& \mathrm{mg} / \mathrm{m}^{3} \text {; an interaction term) + } \\
& \text { fw (for workroom of employment) }+ \\
& \text { fe (for ethnic origin) + } \\
& \text { fs } x \text { smoking habit in pack-years }+ \\
& \mathrm{fx} \text { (for sex) }
\end{aligned}
$$

If exposure to dust is zero the model is not applicable. The fqd is a factor for the interaction term between exposure to dust and fibre quality. The addition of a further interaction term for exposure to dust and workroom (fwd) was not found to contribute a statistically significant amount to variation. Table 7 lists the factors for byssinosis, persistent cough, and chronic phlegm production.

The predictor model constructed for byssinotic symptoms confirms past observations that the odds of a person contracting byssinosis shorten with the period worked in the textile industry, the concentra- 


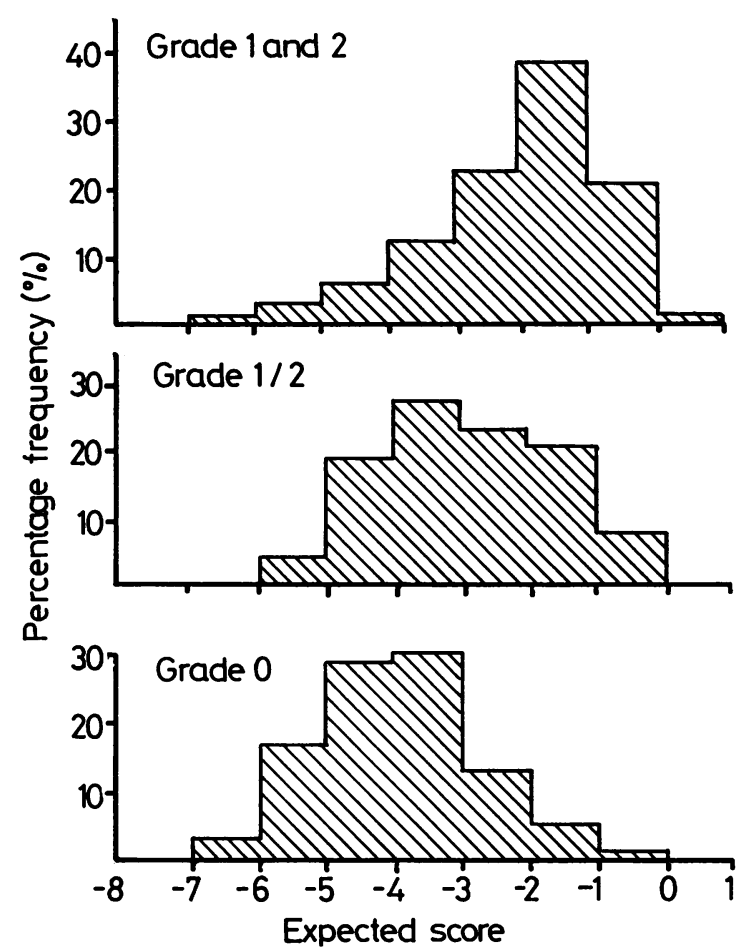

Distribution of expected scores among textile workers who did not experience byssinotic symptoms (grade 0) and among those who experienced the symptoms occasionally

(grade 1/2)or regularly every week (grades 1 or 2).

tion of airborne dust to which he or she is exposed, the coarseness of cotton fibre handled, and the proximity of the workstation to the blowroom and cardroom. ${ }^{13}$ Being of European descent and a smoker may further shorten the odds. The frequency distribution of expected scores calculated from the model for workers who claimed to experience no byssinotic symptoms and those who suffer from grade $1 / 2$ or grades 1 and 2 is displayed by the histograms in the figure.

Factors found to be associated with the prevalence of persistent cough (table 8) were the smoking habit (in pack-years: $p<0.0001$ ), concentration of airborne dust $(p<0.0001)$, nature of workroom $(p<0.0001)$,

Table 8 Factors associated with persistent cough

\begin{tabular}{lccc}
\hline Factor & $\begin{array}{l}\text { Chi- } \\
\text { squared }\end{array}$ & DF & Probability \\
\hline Smoking habit (pack-years) & 100.8 & 1 & $<0.0001$ \\
Years of work experience & 29.4 & 1 & $<0.0001$ \\
Concentration of airborne dust & $15 \cdot 1$ & 1 & $<0.0001$ \\
Workroom of employment & 31.3 & 5 & $<0.0001$ \\
Cotton quality & 22.0 & 6 & 0.0012 \\
Sex & 9.6 & 1 & 0.0019 \\
\hline
\end{tabular}

Table 9 Factors associated with chronic phlegm production

\begin{tabular}{lclc}
\hline Factor & $\begin{array}{l}\text { Chi- } \\
\text { squared }\end{array}$ & DF & Probability \\
\hline Smoking habit (pack-years) & 61.4 & 1 & $<0.0001$ \\
Years of work experience & $15 \cdot 1$ & 1 & $<0.0001$ \\
Workroom of employment & 23.8 & 5 & $<0.0001$ \\
Concentration of airborne dust & 7.4 & 1 & 0.0065 \\
\hline
\end{tabular}

cotton quality $(p=0.0012)$, sex $(p=0.0019)$, and those with the prevalence of chronic phlegm production (table 9) were the smoking habit (in pack-years: $p<0.0001$ ), years of work experience in the textile industry $(p<0.0001)$, nature of workroom $(p<0.0001)$, and concentration of airborne dust $(\mathrm{p}=0.0065)$.

\section{Discussion}

The respiratory questionnaire used in this study was the BMRC Respiratory Symptoms Questionnaire (1982) supplemented by a set of questions to determine byssinotic symptoms' and a second set for diagnosing humidifier fever. ${ }^{6}$ Thus all parts of the questionnaire had already been validated. Because of its complexity, however, answers to it in the follow up study two years later could have been only minimally influenced by the answers given on the first occasion. There were comparatively large gains and losses out of the symptomatic groups, although changes of symptomatological status in the byssinotic group were chiefly confined to individuals with grade $1 / 2$ symptoms (table 4). Changes in prevalence figures over the two years probably reflect genuine long term trends, fewer with byssinotic symptoms as time passes, fewer persistent coughers, but more chronic phlegm producers due possibly to continued smoking and aging.

The overwhelming majority of people (149) who had experienced byssinotic symptoms worked in an opening room or a cardroom $(105 / 1098)$ or in the spinning room $(24 / 744)$ or winding room $(20 / 524)$ of a mill that used medium to coarse or waste cotton (tables 2 and 3). The remaining 33 cases (mainly grade 1/2) out of a population of 2146 were evenly distributed among the remaining $\mathbf{4 0}$ workrooms - that is, beaming, weaving, and sewing rooms or spinning and winding rooms where fine cotton or manmade fibre or a mixture of manmade fibre and cotton was spun. Thus the prevalence of byssinotic symptoms in these workrooms was negligible and may have partly represented cases brought about by heavier exposure at some other times and places and partly artifacts due to misunderstanding or misinterpreting the relevant questions. 
The statistically highly significant relation between ethnic origin and the prevalence of byssinotic symptoms arose because whites contracted the symptoms significantly more frequently than those of Indian or Pakistani descent even taking workyears into account. Of the several possible reasons for this phenomenon, the likeliest is that by the time Indians and Pakistanis came to work in the textile industry (about 15 years ago) it was already relatively clean. Certainly few of them would have been exposed to the airborne dust concentrations that prevailed in the industry up to the beginning of the 1960 s.

The predictor model given in table 10 describes the above distribution of the prevalence of byssinotic symptoms reasonably well. A summation of probabilities over the entire population yields 178, which is the total number of people who have indicated that they experienced the symptoms among the 4583 people for whom full sets of valid data were available and could be used for deriving the model. The model, however, does not segregate well the symptomatic from the asymptomatic person, as the figure indicates. It predicts only eight cases of byssinosis among the 70 who have indicated that they experienced symptoms occasionally (grade 1/2), 18 cases among the 108 who have suffered from them regularly every week (grades 1 and 2), and 152 cases among the 4405 who appeared to be free of the syndrome (grade 0). Thus the model is not useful for determining whether or not a given person should or should not be suffering from byssinotic symptoms but it can be used to predict symptoms in a group of people or to derive a control limit for airborne dust in a given workroom using cotton of a given quality.

Altogether 63 of the $456(13.8 \%)$ who worked in the cardroom of mills using medium to coarse or waste cotton suffered from byssinotic symptoms compared with 142 of $277(51 \%)$ observed by Schilling and Roach in the 1950 s, ${ }^{2} 202$ of $514(38 \%)$ investigated by Molyneux and Tombleson in the $1960 \mathrm{~s},{ }^{3}$ and 85 of 469 cardroom workers $(18 \%$; some of whom, however, handled fine cotton and manmade fibre only) registered by Cinkotai and Whitaker in the 1970s. ${ }^{4}$ Thus the trend in the prevalence of byssinotic symptoms among Lancashire cotton workers is distinctly downward.

Undoubtedly some intensely dusty trades such as stripping and grinding have now been eliminated from the textile cardroom and this would have led to reductions in personal exposure to cotton dust, hence possibly to reductions in the prevalence of byssinotic symptoms. But concentrations of airborne dust in the workzone did not alter much after the 1970s. In 14 of the 22 cardrooms presently studied the current recommended hygiene standard for cotton dust $(<0.5 \mathrm{mg} /$ $\mathrm{m}^{3}$ ) was breached. The quality of dust, however, may have changed, due to the use of cleaner raw cotton and the closure of plants that processed the particularly dirty, coarse fibre. Whereas in the 1970 s the concentrations of airborne Gram-negative bacteria ranged up to several thousands of $\mathrm{cfu} / \mathrm{m}^{3}$ and that of total bacteria to tens of thousands of $\mathrm{cfu} / \mathrm{m}^{3}$ in the present survey the concentration of $300 \mathrm{Gram}$-negative $\mathrm{cfu} / \mathrm{m}^{3}$ and 5000

Table 10 Predictor model of byssinosis, persistent cough, and chronic phlegm production from workyears (wy), dust exposure (de), fibre quality, workroom, ethnic origin, smoking habit (pkyr), and sex (p is probability for contracting symptoms)

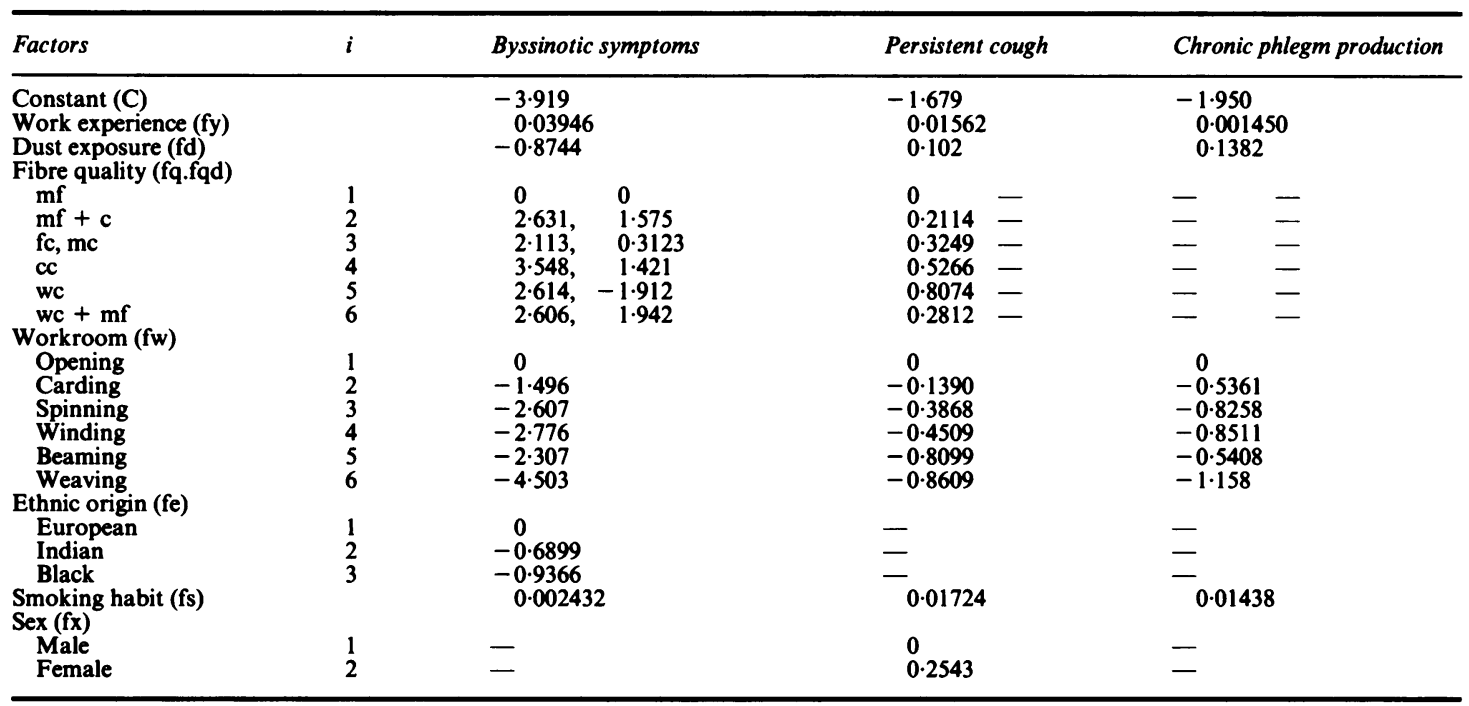

$P=\exp (S) /(1+\exp (S))$ where $S=C+f c / w y+f e(i)+f w(i)+f q(i)+f s . p k y r+(f d+f q d(i)) / l n(d e)$. 
total $\mathrm{cfu} / \mathrm{m}^{3}$ was exceeded consistently only in the cardrooms of mills 11,12 , and 31 (where the prevalence of byssinotic symptoms values were among the highest). Therefore the downward trend in the prevalence of byssinotic symptoms may be associated with the disappearance of much of the bacteria from workroom air

Not unexpectedly, persistent cough and chronic phlegm production were found to be closely associated with the smoking habit expressed in pack-years. These symptoms were, however, significantly exacerbated by factors connected with the occupation, such as the number of years spent working in the textile industry, the level of exposure to dust, the workroom of employment, and, in the case of persistent cough, the quality of fibre handled. These findings confirm the notion held by many that people who suffer from byssinotic symptoms are likely to develop chronic bronchitis towards the end of their working life.

We are grateful to the people who took part in the study, management, and trade unions for consent: Mrs Irene Wilde for carrying out the questionnaire survey and Mr Michael Tereshchuk for technical help. We are greatly indebted to the Cotton Industries War Memorial Fund, the British Cotton Growers Association Ltd's Workpeople Collection Fund, and Courtaulds plc for their financial help without which this project would not have been possible.

\section{References}

I Schilling RSF, Hughes JPW, Dingwall-Fordyce I, Gilson JC. An epidemiological study of byssinosis among Lancashire cotton workers. Br J Ind Med 1956;12:217-27.

2 Roach SA, Schilling RSF. A clinical and environmental study of byssinosis in the Lancashire cotton industry. $\mathrm{Br} \mathrm{J}$ Ind Med 1960;17:1-8.

3 Molyneux MKB, Tombleson JBL. An epidemiological study of respiratory symptoms in Lancashire mills, 1963-6. Br J Ind Med 1970;27:225-34.

4 Cinkotai FF, Whitaker CJ. Airborne bacteria and the prevalence of byssinotic symptoms in 21 cotton spinning mills in Lancashire. Ann Occup Hyg 1978;21:239-50.

5 Generalised linear interactive modelling system. (release 3.77.) Oxford: Royal Statistical Society, 1986.

6 Finnegan MJ, Pickering CAC, Burge PS. The sick building syndrome; prevalence studies. Br Med J 1984;289:1573-5. 